\title{
Was the Mandal Commission Right? Living Standard Differences between Backward Classes and Other Social Groups in India *
}

\author{
Ira N. Gang \\ Department of Economics, Rutgers University \\ gang@economics.rutgers.edu \\ Kunal Sen \\ IDPM, University of Manchester \\ kunal.sen@manchester.ac.uk \\ Myeong-Su Yun \\ Department of Economics, Tulane University \\ msyun@tulane.edu
}

April 2008

\begin{abstract}
Affirmative action has been at the heart of public policies towards the socially disadvantaged in India. Compensatory discrimination policies which have been adopted for the Scheduled Castes (SC) and Scheduled Tribes (ST) since independence were recommended for Other Backward Classes (OBC) by the Mandal Commission established by the Indian government in 1979. We examine why OBC have lower living standards, as measured by per capita household consumption expenditures, relative to the mainstream population, and whether these reasons are similar to those observed for SC and ST. We find that while the causes of the living standard gap for the OBC are broadly similar to those for the SC and ST, the role of educational attainment in explaining the gap is higher in importance for the OBC.
\end{abstract}

Keywords: living standards, caste, reservation policy, decomposition JEL Classifications: I32, O12, J15

\section{Correspondence:}

Myeong-Su Yun, Department of Economics, Tulane University, 206 Tilton Hall, New Orleans, LA 70118, USA. Phone: +1 504 862-8356. Fax: +1 504 865-5869. Email: msyun@tulane.edu.

* We thank Richard Palmer-Jones for helping us with the data. 


\section{Introduction}

Affirmative action policies to increase access to education and employment have been at the core of public policies towards historically disadvantaged or non-dominant groups in both developed and developing countries (Weisskopf 2004, Mcharg and Nicolson 2006, Yuill 2006). Among developing countries, India has had perhaps the longest histories of affirmative action to counter caste and ethnic discrimination (Revankar 1971). Article 46 of the 1950 Constitution pronounces “The State shall promote with special care the educational and economic interests of the weaker sections of the people, and, in particular, of the Scheduled Castes and the Scheduled Tribes, and shall protect them from social injustice and all forms of exploitation.”

Articles 341 and 342 of the Constitution included a list of castes and tribes entitled to such provision, and the castes and the tribes included in these two lists were known as Scheduled Castes (SC) and Scheduled Tribes (ST) respectively. As a consequence of this provision, a policy of compensatory discrimination via reserved positions was implemented both at the national and subnational levels in the allocation of university places and public service appointments (Galanter 1984). ${ }^{1}$ While there were references in the Constitution to an undefined wider category of 'depressed' or 'socially and educationally backward classes of citizens', the identity of these groups -- the 'other backward classes’ -- was left unclear (Bayly 1999), and no special measures such as job reservations or quotas in educational institutions were implemented for these groups at that time.

Recently several papers have examined the causes of economic disparities among social groups in India. These studies attempt to answer why living standards among SC and ST are much

${ }^{1}$ SC and ST were also favored by the Indian government in land redistribution policies, loan allocations, and a large number of other official development programs. Quotas were also introduced for SC and ST in state legislatures and local governments. 
lower than the rest of the population (Bhaumik and Chakrabarty 2006, Kijima 2006, Borooah 2005, and Gang, Sen and Yun 2008). Gang, Sen and Yun (2008) show that along with differences in educational attainment between SC and Other households, the occupational characteristics of SC households places them at a disadvantage compared to Other households, while for ST households, locational factors rather than occupational characteristics are more important in explaining their higher poverty status. Borooah, Dubey and Iyer (2007) explicitly address the effectiveness of job reservations on the economic opportunities of persons belonging to the SC and ST, finding that the boost provided by job reservations in raising the proportion of SC and ST individuals in regular salaried employment is 5 percent.

During 1990 riots and other forms of civil disruption occurred throughout India to protest the proposed extension of quotas in educational institutions and public sector jobs to Other Backward Classes (OBC). These were known as the anti-Mandal Commission riots, named after the Commission which recommended the extension of the quotas in admission educational institutions and in public sector jobs to the OBC. The issue of whether the compensatory discrimination that have been provided by the Indian state to SC and ST should also be provided to OBC has remained at the heart of the affirmative action debate in India, with recent proposals to extend the reservation policies for OBC to elite institutions of higher education and to the private sector (Thorat 2004, Thorat, Aryamma and Negi 2005). So far, there have been no studies that have examined the economic status of the $\mathrm{OBC}$, and compared the determinants of the economic conditions of the OBC to the those of SC and ST social groups and the remainder of the population. Given the far-reaching implications of the Mandal Commission findings and recommendations for India's social fabric and the relevance of affirmative action policies in India for other countries with similar disparities 
between social groups, this is an important gap in the literature.

This paper examines the determinants of living standards for OBC and other social groups in India. Living standards in SC, ST and OBC households are much lower than the mainstream population, comprising the Hindu ‘forward castes’ and other religions, including those belonging to the Christian, Muslim and Sikh religious faiths. We call these households 'Other' households. ${ }^{2}$ We use monthly per capita expenditure (PCE) as the measure of living standards. In urban areas. overall, monthly PCE is 978.568 rupees. This varies widely by group, with PCEs at 686.897, 772.917, 849.743, and 1143.760, respectively for SC, ST, OBC and Other households. In rural areas, monthly PCE is 521.563. By group we see PCEs of 449.924, 412.533, 511.520, and 624.774, respectively for SC, ST, OBC and Other households.

We study differences in living standards among social groups in India using Oaxaca decomposition analysis (Oaxaca 1973). Our approach allows us to develop a better grasp of the sources of the differences in living standards among different social groups in India, in particular whether differences in the amounts of schooling, occupational choice and demographic characteristics hold the key to understanding the living standard gap, and whether the income generating strength of household or individual characteristics (e.g., education and occupation) are different for each group.

We investigate whether the causes of lower living standards among OBC households are similar to SC and ST households. If a similar set of causes explain the lower living standards of

\footnotetext{
${ }^{2}$ To make our social groups comparable, we did not confine our analysis of Other households to the 'forward caste' Hindu population, as several SC and OBC households were also classified as belonging to religions other than Hinduism. The individuals in these households may have been originally Hindu, but have converted to a different religion.
} 
OBC as well as SC/ST households than Other households, it provides a stronger justification for the Mandal Commission's finding that OBC shares the same economic status in Indian society as the SC and ST. Based on our findings on the causes of lower living standards - and in particular, the roles of education and occupation- among OBC households in comparison to SC and ST households, we evaluate the specific reservation policies that have been proposed by the Mandal Commission.

In the next section, we summarize the historical background of the Mandal Commission and its main findings and recommendations. Section 3 discuss the mean characteristics of the social groups in our analysis - Other Backward Castes, Scheduled Castes, Scheduled Tribes and the Other household group. Section 4 investigates the determinants of living standards for these social groups, examining the relative influence of various socio-economic variables on monthly per capita expenditures. Section 5 employs decomposition analysis using regression coefficients to examine and explain living standard gaps between Other Backward Castes, Scheduled Castes, Scheduled Tribes on one hand and the mainstream population on the other. Finally, Section 6 provides a summary of our study and its main conclusions.

\section{The Mandal Commission: Extending Affirmative Action to Other Backward Classes}

In 1979, a commission under the chairmanship of B.P.Mandal - popularly known as the Mandal Commission - was established by the ruling Janata Party under the Prime Ministership of Morarji Desai with the objective of identifying the Other Backward Classes (OBC). In 1980, it published its findings, placing a total of 3428 'communities' in the OBC category, comprising 54.4 percent of the country’s population (Bayly 1999). The Mandal Commission recommended that there should be employment quotas in public sector organizations (including nationalized banks and private 
sector undertakings which received financial assistance from the government in one form or the other) and reserved places in higher educational institutions of 27 percent for $\mathrm{OBC}$ in addition to the 22.5 percent job quotas and seats in higher educational institutions that were already in place for SC and ST (Ramaiah 1992). The figure of 27 percent was arrived at as the Supreme Court limited total reservations to under 50 percent.

Due to a change in the government in 1979, the report from the Mandal Commission was shelved. In 1989, a successor party to the Janata Party - the Janata Dal - achieved power as the leading element of a national coalition government under the Prime Ministership of V.P. Singh and announced plans to implement the Mandal Commission recommendations, significantly increasing quotas in public sector employment and in university admissions for the communities which had been classified as OBC by the Mandal Commission. The announcement led to significant violent resistance in many parts of India, including a series of widely publicized self-immolations by highcaste students (Bayly 1999). In recent years, with the coming to power of the Congress-led Government of Manmohan Singh in 2004, there have also been proposals to extend the job quotas to private sector jobs and to certain privileged institutions of higher education which had been omitted earlier from the reservations policies for OBC earlier.

Unlike the case of compensatory discrimination policies for SC and ST implemented in the immediate post-independence period which were widely regarded as justified and did not cause much controversy, there has been significant criticism of the Mandal Commission findings and recommendations. Firstly, the methods and criteria adopted by the Mandal Commission to define a 'backward class' were widely regarded as flawed raising skepticism whether the communities determined to be $\mathrm{OBC}$ by the Commission were truly socially disadvantaged or deserving of the 
massive welfare programs subsumed under reservation policy (Beteille 1992, Radhakrishnan 1996). Secondly, several observers felt that the reasons successive governments tried to implement the Mandal Commission recommendation had more to do with political factors than economic and social justification, as several of the communities included in the Mandal Commission's list of OBC formed important 'vote banks' for political parties both in power and in opposition (Sivaramayya 1996, Bayly 1999).

\section{Data and Descriptive Statistics}

For our analysis we use the 55th round of India’s National Sample Survey (NSS) on consumer expenditure in rural and urban areas collected in 25 states and 7 Union Territories. The survey period extended from July 1999 to June 2000. The 55th round was the first time the NSS demarcated OBC from other non-scheduled caste Hindus in the expenditure survey. In previous rounds, expenditure data on OBC were combined with other non-scheduled caste Hindus, making earlier examination of differences in living standards between OBC and Other households impossible. ${ }^{3}$

The NSS data is a cross-section of a geographically distributed random sample of households. Besides information on household consumer expenditure and demographic behavior, the NSS contains detailed questions on other household characteristics such as the educational level and occupation of the head of the household. Since the NSS provides expenditure data by household, our estimates of monthly per capita expenditures are at the level of the household, not at the level

\footnotetext{
${ }^{3}$ It is possible that the discrimination against OBC had already been reduced when the 1999-2000 survey was conducted as compared to the time of the Mandal Commission study, because several Indian states may have implemented the Mandal Commission recommendations before the survey.
} 
of the individual. ${ }^{4}$ We restrict our sample to households where the age of the head of the household is between 20 and 70 years.

Tables 1 and 2 show the mean characteristics of the sample rural and urban households, respectively. We first describe the mean characteristics of rural households (Table 1). Considering the demographic characteristics of the four groups of households, we find that OBC, SC and ST households have a lower mean age for the head of the household compared to Other households. OBC, SC and ST households are also smaller than Other households - the mean household size for OBC, SC and ST households are 5.10, 4.88 and 4.96 respectively, compared with a mean household size of 5.17 for Other households. Other households own the most land (0.97 hectares), followed by ST households (0.82) and OBC households (0.71). The average land holding of SC households at 0.31 hectares is substantially less than the average land holdings of the other three social groups.

A much higher proportion of SC and ST households are not literate (61.7 percent and 65.3 percent, respectively), compared with OBC households (50.5 percent) and Other households (35.9 percent). With respect to occupation, 15.5 percent of OBC households are self-employed in nonagriculture, 31.3 percent as agricultural laborers, 7.9 percent as non-agricultural laborers, 35.2 percent are self-employed in agriculture while 10.2 percent are classified in a residual category which we term 'miscellaneous'. In the case of SC households, 12.1 percent of SC households are self-employed in non-agriculture, 54.0 percent as agricultural laborers, 9.6 percent as nonagricultural laborers, 16.4 percent are self-employed in agriculture while 7.8 percent are classified as 'miscellaneous'. For ST households, 5.4 percent are self-employed in non-agriculture, 44.1

\footnotetext{
${ }^{4}$ This distinction becomes important when there are significant differences in the intra-household consumption of food and other necessities across the SC, ST, OBC and Other households.
} 
percent are agricultural laborers, 8.1 percent are non-agricultural laborers, 36.7 percent are selfemployed in agriculture while 5.7 percent are in 'miscellaneous' occupations. Finally, for Other households, 15.0 percent are self-employed in non-agriculture, 20.9 percent are agricultural laborers, 6.4 percent are non-agricultural laborers, 41.4 percent are self-employed in agriculture while 16.3 percent are in 'miscellaneous' occupations. Thus, a greater proportion of OBC households are selfemployed in agriculture as compared to SC households. A lower proportion of OBC households are agricultural laborers as compared to SC and ST households.

We next describe the mean characteristics of urban households (Table 2). Similar to rural households, we find that OBC, SC and ST households have a lower mean age for the head of the household compared to Other households. Similarly, OBC, SC and ST households are also smaller than Other households - the mean household size for OBC, SC and ST households are 4.60, 4.81 and 4.56 respectively, compared with a mean household size of 4.50 for Other households.

The proportion of Other households who are illiterate at 12.3 percent is less than half of the next literate group - OBC households - where the illiteracy rate is 25.0 percent. The illiteracy rate for SC and ST households are 37.1 percent and 34.2 percent respectively. With respect to occupation, 37.9 percent of OBC households are self-employed, 36.6 percent are salaried workers, 18.6 percent are casual laborers and 6.9 percent are classified in a residual category termed 'miscellaneous'. In the case of SC households, 26.8 percent are self-employed, 39.4 percent are salaried workers, 28.9 percent are casual laborers and 4.8 percent are in 'miscellaneous' occupations. In the case of ST households, 23.8 percent are self-employed, 40.5 percent are salaried workers, 25.4 percent are casual laborers and 10.3 percent are in 'miscellaneous’ occupations. Finally, for Other households, 36.4 percent are self-employed, 47.6 percent are salaried workers, 7.7 
percent are casual laborers, and 8.3 percent are in 'miscellaneous' occupations. The proportion of SC and ST households who are casual laborers are higher than for OBC and Other households. The proportion of OBC households where the head of the household is a salaried worker is not very different than SC and ST households.

\section{Determinants of Living Standards}

To study determinants of living standards, we regress log monthly per capita expenditure on various household characteristics in addition to state/region fixed effects. The regression equation is $y=X \beta+e$, where $y, X$, and $\beta$ are, respectively, an $N \times 1$ vector of log monthly per capita expenditure, an $N \times K$ matrix of independent variables, and a $K \times 1$ vector of coefficients. We now discuss the specification of our regression equation, which we estimate using ordinary least squares for households in the Others group, other backward castes (OBC), scheduled castes (SC) and scheduled tribes (ST), separately. We also discuss the implications of the estimated coefficients on the determinants of living standards.

Our focus is on education and occupation. To capture the effect of education on the household's living standards, we use dummy variables corresponding to the highest educational level completed by the head of the household. We include dummy variables corresponding to 'literate, below primary level', 'literate, below secondary level', 'literate up to secondary level', and 'literate, higher secondary and above’ (the reference group is households where the head of the household is not literate). With respect to occupation, we include dummy variables corresponding to four occupational groups for rural households - self-employed in non-agriculture, self-employed in agriculture, agricultural labor and non-agricultural labor - and three occupational categories for 
urban households - self-employed, waged/salaried workers, and casual labor (with the reference group for both rural and households being the occupational category we termed the 'miscellaneous' category). ${ }^{5}$

Besides the explanatory variables capturing occupation and educational levels, we include in our analysis a number of background and demographic variables. We include the generational impact reflected by the age of the person. We use two variables: age (number of years), and agesquared (number of years of age-squared divided by 100), to reflect the non-linear effects of age on living standards. We incorporate the effect of household size on living standards, as previous studies have noted a negative relationship between per capita expenditures and the size of the household (Krishnaji 1984). Given the possible presence of economies of scale in household consumption, we include household size squared as an additional control variable. We also include total cultivated land owned by the household as a measure of the household's wealth status for rural households.

We include controls for the location of the household. There are significant differences in rural living standards across Indian states, with states in North-Western India (Haryana, Punjab) along with the state of Kerala having higher living standards than the national average (Datt and Ravallion 1998). In contrast, the living standards in Assam, Bihar and Orissa are much lower than the national average. ${ }^{6}$ Furthermore, there is non-negligible variation in rural living standards within

\footnotetext{
${ }^{5}$ The NSS classifies rural and urban households in occupational categories according to the main source of income reported for each surveyed household. This is called the "principal occupation code" of the household. The principal occupation is defined to be that which contributes at least $50 \%$ of household income. The category we term 'miscellaneous' includes those where no one income source exceeds $50 \%$ or more of total income. Thus, the households in this category have very diversified income sources or more than one earning member.

${ }^{6}$ There are 32 states and union territories in the 55th round of the NSS consumer expenditure survey.
} 
Indian states across NSS regions and these variations are crudely associated with differences in agroecological conditions which may be vastly different within a state, parts of which may be more similar to those prevailing in geographically contiguous states (Palmer-Jones and Sen 2003). ${ }^{7}$ A similar difference in living standards across Indian states is also evident for urban households. More industrialized states such as Tamil Nadu and West Bengal have higher urban living standards than less industrialized states such as Orissa and Uttar Pradesh. Dubey, Gangopadhyay and Wadhwa (2001) find that per capita expenditures of urban households are increasing in the size of the city in which the households are located, which could be attributed to the presence of stronger agglomeration economies in the larger cities. This suggests that there may also be significant living standards differences across NSS regions within Indian states, with regions that contain larger cities having higher living standards on average than regions with smaller cities. The omission of dummy variables to capture the location of the household may bias the results if the OBC households are mostly residing in Indian states and NSS regions where living standards are lower, and if these lower living standards are due to state-level and sub-state NSS region-level factors exogenous to the household such as the nature of state-level public policies toward poorer households, agro-climactic factors or the presence of agglomeration economies. We present our results with the inclusion of NSS region fixed effects.

The OLS estimates of the regression equation for the rural sample are reported in Table 3, and for the urban sample in Table 4. We first describe our results for the rural sample. The estimated coefficients show that greater educational attainment is associated with a statistically significant

\footnotetext{
${ }^{7}$ NSS regions are groupings of contiguous districts within states. There are 82 regions in the 55th round of the NSS consumer expenditure survey.
} 
increase in per capita expenditure, with everything else held constant. This is true for all four household groups. However, higher educational attainment from the secondary level up seems to lead to a greater increase in per capita expenditures for Other households when compared with OBC, SC and ST households.

We now turn our attention to occupation and its impact on per capita expenditure. Compared with the occupational category 'miscellaneous', all other occupational categories have lower per capita expenditure, i.e., those households are more likely to have lower living standards for all four social groups. Agricultural laborer household are more likely to be poorer among all occupational groups, controlling for other determinants. Interestingly, OBC households who are self-employed in agriculture are relatively better off compared to those in SC, ST and Other households, as evident in a smaller magnitude in the coefficients on self-employed in agriculture for OBC households as compared to SC, ST and Other households. With respect to demographic factors, higher aged heads of households are associated with a higher per capita expenditure. However, this relationship is nonlinear, with further increases in age leading to less than proportionate increases in per capita expenditures. A non-linear relationship is also found between living standards and household size; per capita expenditure first decreases then increases. The possession of cultivable land seems to have a positive effect of similar magnitude on per capita expenditure for OBC, SC and ST households, though not for Other households.

The results imply that rural households that are larger, where the head of the household is not literate, is an agricultural laborer, is younger in age, and possess a smaller amount of land have lower living standards. We also find that the effects of explanatory variables on per capita expenditure vary over social groups. 
Turning now to the results for urban households in Table 4, we find that as in the case of rural households, higher educational achievements have a monotonically increasing effect on per capita expenditures for all social groups. However, the return to education in terms of increasing living standards is most evident among ST and Other households as compared to OBC and SC households. With respect to occupation, casual laborers are most likely to have lower living standards, and this is observed for all social groups. Salaried workers are likely to have higher living standards than other occupations in the case of OBC and SC households, though this is not the case with ST and Other social groups, where the coefficients on the dummy variable for workers who are salaried for these two groups are not statistically significant. As in the case of rural households, age and household size have similar non-linear effects on per capita expenditures. While per capita expenditures increase and then decrease with the age of the head of the household, per capita expenditures decrease then increase with the size of the household.

\section{Accounting for Differences in Living Standards}

In this section, we seek to explain why living standards are lower among OBC households as compared to Others, and see whether the determinants in the living standards gap between OBC and Other households is different than those for SC versus Other households, and ST versus Other households.

Sources of differences in living standards can be found from differences in household characteristics across groups (characteristics effect) and from differences in returns to household characteristics across groups (coefficients effect). The characteristics effect relies on the possibility that the characteristics or attributes of households contributing to living standards may differ among 
groups. For example, one group may have less education than another group, or be in “bad” jobs. The characteristics effect reflects how differences in the attributes of households among groups affect differences in living standards.

The coefficients effect relies on the possibility that the effectiveness of household characteristics, reflected in regression estimates, may vary across groups. For example, education may be less effective in raising living standards in scheduled and OBC households compared with Other households. The coefficients effect reflects how differences in the regression coefficients across groups affect living standards.

As argued by Gang, Sen and Yun (2008), interpreting these two effects is always difficult and controversial as shown in studies decomposing wage differentials. The popular interpretation is that the characteristics effect is not due to discrimination while the coefficients effect may be related to an outcome of unequal treatment by society (discrimination). Though differences in characteristics are supposed to reflect differences in income generating qualifications and credentials possessed by various groups, it is possible that the disparity in attributes might result from widespread discrimination against the scheduled and OBC groups in terms of educational opportunity and occupational choice. On the other hand, it is not clear that discrimination is the only source for the existence of the coefficients effect. For example, educational quality may differ between scheduled and non-scheduled households for reasons not due to discrimination. Hence, the differences in the coefficients on education may also capture differences in education quality between the scheduled and non-scheduled in addition to capturing discrimination. Therefore, our interpretation is that the coefficients effect captures the amount of the living standard gap caused by the differences in the effectiveness of characteristics in enhancing living standards between the comparison groups. These 
caveats should be kept in mind in interpreting decomposition results.

Using regression estimates of living standards, we can decompose the average differences in living standards measured in terms of per capita monthly expenditure between group $A$ and $B$ as follows:

$$
\bar{y}_{A}-\bar{y}_{B}=\left(\bar{X}_{A}-\bar{X}_{B}\right) \beta_{A}+\bar{X}_{B}\left(\beta_{A}-\beta_{B}\right),
$$

where the first and the second components represent the characteristics effect and the coefficients effect, respectively, and "over bar" represents the value of the sample average. Since OLS is used, the residuals effect $\left(\bar{e}_{A}-\bar{e}_{B}\right)$ disappears. ${ }^{8}$

We now discuss our empirical findings from the decomposition analysis. We focus on the percentage share that tells us what percentage of the total living standard gap is accounted for by that particular element or group of elements. We discuss the overall effects first, and then break down the overall effects into smaller subgroups. We discuss the living standard gap of OBC relative to Other households in Table 5, for SC relative to Other households in Table 6, and that of ST compared with the Other households in Table 7. In Tables 5, 6 and 7 we provide the results of the aggregate

\footnotetext{
${ }^{8} \mathrm{~A}$ decomposition equation with a different parameterization, that is, $\left(\bar{X}_{A}-\bar{X}_{B}\right) \beta_{B}+\bar{X}_{A}\left(\beta_{A}-\beta_{B}\right)$, is possible; our results with it are not substantially different from those presented here and are available from the authors upon request. Another issue when interpreting the decomposition results is that the coefficients effect in the detailed decomposition is not invariant to the choice of omitted groups when dummy variables are used (see Oaxaca and Ransom 1999, for details of this issue). We follow a solution suggested by Yun (2005) that, if alternative reference groups yield different estimates of the coefficients effects for each individual variable, it is natural to obtain estimates of the coefficients effects for every possible specification of the reference groups and take the average of the estimates of the coefficients effects with various reference groups as the "true" contributions of individual variables to differentials. While appearing cumbersome, this can be accomplished with a single estimation. We can transform our regression estimates into a normalized equation and use the normalized equation for our decomposition (see Yun 2005 and Gang, Sen and Yun 2008, pages 68-69).
} 
breakdown, and of key groups of variables, for both rural and urban samples for the each of the paired comparisons.

We proceed by first discussing the aggregate effects and sub-aggregate effects for rural OBC households (Table 5, first half of the table). The Aggregate Effects row shows the overall effects of characteristics versus coefficients in explaining differences in living standards. The top panel shows that 54.7 percent of the difference in living standards between the OBC and Other households is explained by the differences in the levels of characteristics possessed by the two groups, while 45.3 percent by the differences in the regression coefficients. Both aggregate characteristics and coefficients effects are significant at the 1 percent level of significance. If in both groups the various variables influencing living standards had the same strength (their coefficients had been equal), then 45.3 percent of the lower living standards in OBC households compared to Other households would disappear. On the other hand, if both groups had the same characteristics, 54.7 percent of the living standard gap would disappear.

In the first half of Table 5, we also see the breakdown of characteristics and coefficients effects into important variable groupings for the rural sample. We see the importance of the education effect for occupation in determining the living standard gap, contributing 22.5 percent. The coefficients effect of education is a negative 3.8 percent. Thus, it is the characteristics effect of education rather than its coefficients effect, which explains why OBC rural households have a much lower level of living standards than Other households. Occupational structure is also important, but not as much as education. The characteristics and coefficients effects of education contributes 12.4 and -2.4 percent respectively to the living standard gap.

Among the control variables, land owned, household size, and age do not have contribute 
significantly to the living standard gap. The characteristics and coefficients effects of land owned contribute 3.8 and - 4.8 percent respectively to the living standard gap. The coefficients effect of age structure (age and age-squared taken together) is not significant while the characteristics effect in positive and significant, though small. For household size we find the characteristics effect is negative, and the coefficients effect is positive and large. Household size differences reduce the living standard gap, but differences in coefficients increase the living standard gap. ${ }^{9}$ Finally, locational factors are important in explaining the large gap in living standards between rural OBC and Other households - the characteristics and coefficients effects of the NSS region dummy variables contribute 24.3 percent to the living standard gap.

Moving now to urban households (second half of Table 5), we find that 72.2 percent of the difference in living standards between the OBC and Other households is explained by the differences in the levels of characteristics possessed by the two groups, while 27.8 percent by the differences in the regression coefficients. Both aggregate characteristics and coefficients effects are significant at the 1 percent level of significance. The characteristics effect of education along with the coefficients effect of age dominate other effects in explaining the living standard gap between OBC and Other households. The characteristics effect of education explains 46.2 of the living standard gap while the coefficients effect of age explains 82.7 percent. The coefficients effect of education explains only a negative 1.0 percent of the living standard gap. Interestingly, occupational structure has a very limited role to play in explaining the urban living standard gap for OBC households - the characteristics and coefficients effects of education are 9.1 and -2.5 percent, respectively. Locational

\footnotetext{
${ }^{9}$ As seen in Table 1, OBC households are smaller in size than Other households, and our analysis suggests that the likelihood of a lower living standards is positively related to household size.
} 
factors (as captured by the NSS regional dummies) are less important in explaining the living standard gap for urban households compared to rural households.

We now examine the determinants of differences in living standard between SC and Other households in Table 6. For the rural sample, the aggregate characteristics and coefficients effects for SC households are very similar to OBC households (first half of Table 6). The aggregate characteristics effect contributes 56.2 percent of the living standard gap. The coefficients effect contributes 43.8 percent of the living standard gap. Similar to OBC households, a large proportion of the difference in living standards can be explained by the characteristics effects of education and occupation - these contribute 21.8 percent each of the living standard gap. However, the contribution of the coefficients effects for these two variables is small, -8.1 percent for education and -5.4 percent for occupation. The characteristics and coefficients effects of other variables are small, except the coefficients effect of age at 11.0 percent, and the combined characteristics and coefficients effects of the NSS Region dummy variables at 29.0 percent.

As in the case with rural households, the aggregate characteristics and coefficients effects for urban SC households is very similar to urban OBC households - the characteristics and coefficients effects contribute 70.6 and 29.4 percent of the living standard gap respectively (second half of Table 6). The characteristics effect of education explains much of the living standard gap, contributing 42.4 percent to the latter. The coefficients effect of age also contributes 39.3 percent. The characteristics effect of occupation contribute 11.5 percent of the urban living standard gap for SC households. Other variables have little role to play in explaining the living standard gap. Locational factors have a minor role ro play in explaining the living standard gap.

Finally, examining the determinants of the living standard gap for ST vs Other households, 
the aggregate characteristics and coefficients effects for rural ST households is 53.5 and 46.5 percent respectively (first half of Table 7). The characteristics effects of education and occupation contribute 18.4 percent and 12.1 percent respectively of the rural living standard gap. The contribution of the coefficients effects for these two variables is small, -5.2 percent for education and 0.1 percent for occupation. Locational factors explain much more of the ST rural living standard gap than they do of the OBC and SC rural living standard gap, with the combined characteristics and coefficients effects of NSS Region dummy variables explaining 38.4 percent of the rural living standard gap for ST households. Among other variables, the coefficients effect of household size at 13.0 percent is large.

In the case of urban households, the aggregate characteristics and coefficients effects of ST households contribute 66.8 and 33.2 percent of the living standard gap (second half of Table 7). As in the case of SC households, the characteristics effect of education and the coefficients effect of age dominate all other effects, contributing 36.3 percent and 32.2 percent of the urban living standard gap respectively. The coefficients effect of education explains only 0.7 percent of the living standard gap. The characteristics and coefficients effects of occupation contributes 11.2 percent and -5.4 percent of to the living standard gap of urban ST households.

The overall findings suggest a rather murky picture of social justice in India. In urban areas, the decomposition analysis suggests that the characteristics effects dominates the coefficients effect, explaining around 65-70 percent of the difference in living standards between SC, ST and OBC households on one hand and Other households on the other, while in rural areas, both characteristics and coefficients effects have roughly equal impacts in explaining the difference in living standard gap. This may be due a lower level of discrimination against ST, SC and OBC in urban labor markets 
than rural labor markets. Differences in educational attainment are the most important source of the characteristics effect in urban areas, explaining between 36 to 46 percent of the differences in living standards for these social groups. Differences in occupational characteristics are relatively less important in determining the urban living standard gap, explaining around 9-11 percent of the difference in living standards. Differences in educational attainment are more important for OBC (46.2\%) than for SC (42.4\%) and ST (36.3\%). Locational factors, characteristics and coefficients effects combined, play a small role in explaining the urban living standard gap for OBC, SC and ST households, explaining around 11-12 percent of the gap. Interestingly, differences in returns to education do not explain the lower living standards of OBC, SC and ST households as compared to Other households.

With respect to the rural living standard gap, the characteristics effects of both education and occupation matter in explaining the former for all three social groups. The characteristics effect of education matters slightly more for OBC (22.5\%) and SC households (21.8\%) as compared to ST households (18.4\%). The characteristics effect of occupation matter much more for SC households (21.8\%) as compared to OBC (12.4\%) and ST households (12.1\%). Surprisingly, the coefficients effect of education is negative for all three social groups, suggesting that the returns to education lead to higher living standards for OBC, SC and ST households as compared to Other households. The coefficients effect of occupation is relatively unimportant in explaining the rural standard gap. Differences in locational distribution are more important in explaining the living standard gap for ST households as compared to SC and OBC households.

Our aggregate results indicate that the causes of the living standard gap between the $\mathrm{OBC}$ and Others are broadly similar to those for the SC and ST - the characteristics effects explain much of 
the urban living standard gap, while the coefficients and characteristics effects have approximately equal roles in explaining the rural living standard gap. The disaggregated results indicate that the causes of lower living standards for OBCs in urban areas are broadly similar to the other two social groups and can be attributed mainly to lower levels of educational attainment among all three social groups as compared to the rest of the population. However, in rural areas, the causes of the lower living standards of the OBC as compared to the Others are not identical to those for SC and ST, with locational and occupational characteristics playing a less important role as compared to differences in educational characteristics.

\section{Summary and Conclusions}

The Mandal Commission was set up in 1979 by the Janata Party government under Prime Minister Morarji Desai with a mandate to identify the socially or educationally backward. The Mandal Commission recommended compensatory discrimination policies similar to those adopted after independence for the Scheduled Castes and Scheduled Tribes for a large proportion of the Indian population who were classified as Other Backward Classes. The recommendations of the Mandal Commission have generated significant controversy since their publication in 1980.We use the 55th round of India's National Sample Survey (NSS) on consumer expenditure which for the first time distinguishes Other Backward Classes from other castes and tribes to examine whether the Other Backward Classes deserves recognition as a distinct social group requiring special social welfare programs.

By employing regression estimates of per capita expenditure and an Oaxaca decomposition analysis, we study how these differences in living standards arise. We undertake the decomposition 
analysis separately for rural and urban households, as the underlying causes for the differences in living standards may be different rural and urban areas. Using a decomposition equation we can explain differences in living standards in terms of differences in characteristics (characteristics effect) and differences in the coefficients (coefficients effect).

We find that the causes of the living standard gap between the Other Backward Classes and Others are broadly similar to those for the Scheduled Castes and Scheduled Tribes - the characteristics effects explain much of the urban living standard gap, while the coefficients and characteristics effects have approximately equal roles in explaining the rural living standard gap. In particular, for Other Backward Classes households, lower levels of educational attainment as compared to Other households are crucial in explaining the living standard gap for Other Backward Classes households, whether in rural or urban areas. In the case of Scheduled Castes and Scheduled Tribes households, along with lower levels of educational attainment, occupational structure (in the case of Scheduled Castes households) and locational characteristics (in the Scheduled Tribes households) also seem to matter in explaining living standard gap, especially in rural areas. We therefore conclude that the Mandal Commission may have been partly right and partly wrong in its recommendations: while seat reservations in educational institutions may help to some extent in reducing the difference in living standards between the Other Backward Classes and the mainstream population, it is less certain that job quotas will contribute to the same extent. 


\section{REFERENCES}

Bayly, S. (1999), Caste, Society and Politics in India, Cambridge: Cambridge University Press

Beteille, A.(1992), The Backward Classes in Contemporary India. Delhi: Oxford University Press.

Bhaumik, S.K. and M. Chakrabarty (2006), Earnings Inequality in India: Has the Rise of Caste and Religion based Politics in India had an impact?, IZA Discussion Paper 2008.

Borooah, V.K. (2005), Caste, Inequality and Poverty in India, Review of Development Economics 9(3), 399-414.

Booroah, V., A. Dubey and S. Iyer (2007), The Effectiveness of Job Reservations: Caste, Religion and Economic Status in India, Development and Change 38(3), 423-445.

Datt, G. and M. Ravallion (1998), Why Have Some Indian States Done Better Than Others at Reducing Rural Poverty?, Economica 65(257), 17-38.

Dubey, A., S. Gangopadhyay and W. Wadhwa (2001), Occupational Structure and Incidence of Poverty in Indian Towns of Different Sizes, Review of Development Economics 5(1), 49-59.

Galanter, M. (1984), Competing Equalities: Law and the Backward Classes in India, Berkeley: University of California Press.

Gang, I., K. Sen and M.-S.Yun (2008), Poverty in Rural India: Caste and Tribe, Review of Income and Wealth 54(1), 50-70.

Kijima, Y. (2006), Caste and Tribe Inequality: Evidence from India, 1983-1999, Economic Development and Cultural Change 54(2), 369-404.

Krishnaji, N. (1984), Family-size, Levels of Living and Differential Mortality in Rural India - Some Paradoxes, Economic and Political Weekly 19(6), 248-258.

Mcharg, A and D. Nicolson (2006), Debating Affirmative Action, London: Blackwells.

Oaxaca, R. (1973), Male-Female Wage Differentials in Urban Labor Markets, International Economic Review 14 (3), 693-709.

Oaxaca, R.and M. R. Ransom (1999), Identification in Detailed Wage Decompositions, Review of Economics and Statistics 81(1), 154-157.

Palmer-Jones, R. and K. Sen, (2003), What has luck got to do with it? A regional analysis of poverty and agricultural growth in rural India, Journal of Development Studies 40(1), 1-33. 
Radhakrishnan, P. (1996), Mandal Commission Report: A Sociological Critique, in M.N. Srinivas (ed.), Caste: Its Twentieth Century Avatar, Delhi: Penguin India.

Ramaiah, A. (1992), Identifying Other Backward Classes in India, Economic and Political Weekly, 6th June: 1203-1207.

Revankar, R.G.(1971), The Indian Constitution - A Case Study of Backward Classes. Rutherford: Fairleigh Dickinson University Press.

Sivaramayya, B. (1996), The Mandal Judgement: A Brief Description and Critique, in M.N. Srinivas (ed.), Caste: Its Twentieth Century Avatar, Delhi: Penguin India.

Thorat, S.K. (2004), Caste System in India: Social and Economic Exclusion and Poverty, Indian Institute of Dalit Studies, New Delhi.

Thorat, S.K., Aryamma, and P. Negi (2005), Reservations and the Private Sector: Quest for Equal Opportunity and Growth, Delhi: Rawat Publications.

Weisskopf, T. (2004), Affirmative Action in the United States and India: A Comparative Perspective, New York: Routledge.

Yuill, K. (2006), Richard Nixon and the Rise of Affirmative Action: The Pursuit of Racial Equality in an Era of Limits, New York: Rowman and Littlefield.

Yun, M.-S. (2005), A Simple Solution to the Identification Problem in Detailed Wage Decomposition, Economic Inquiry 43(3), 766-772. 
Table 1: Sample Means, Rural Households

Variables

Other Backward Scheduled Castes

Scheduled Tribes

Others Castes

\begin{tabular}{|c|c|c|c|c|c|c|c|c|}
\hline & Mean & S.D. & Mean & S.D. & Mean & S.D. & Mean & S.D. \\
\hline Monthly Per Capita Expenditure & 511.520 & 342.603 & 449.924 & 346.036 & 412.533 & 221.478 & 624.774 & 403.991 \\
\hline Log of Monthly Per Capita Expenditure & 6.123 & 0.451 & 6.007 & 0.424 & 5.919 & 0.438 & 6.306 & 0.485 \\
\hline \multicolumn{9}{|c|}{ Demographic and Other Control Variables } \\
\hline Age & 43.958 & 12.423 & 42.654 & 12.215 & 41.996 & 12.786 & 44.699 & 12.454 \\
\hline Household Size & 5.103 & 2.557 & 4.884 & 2.271 & 4.964 & 2.280 & 5.174 & 2.625 \\
\hline Land Owned (hectares) & 0.710 & 1.502 & 0.313 & 0.806 & 0.817 & 1.296 & 0.971 & 2.172 \\
\hline \multicolumn{9}{|l|}{ Education Variables } \\
\hline Not Literate & 0.505 & 0.500 & 0.617 & 0.486 & 0.653 & 0.476 & 0.359 & 0.480 \\
\hline Literate, below primary & 0.155 & 0.361 & 0.144 & 0.351 & 0.137 & 0.344 & 0.154 & 0.361 \\
\hline Literate, below secondary & 0.231 & 0.421 & 0.171 & 0.376 & 0.152 & 0.359 & 0.277 & 0.448 \\
\hline Literate, secondary & 0.061 & 0.239 & 0.040 & 0.197 & 0.028 & 0.164 & 0.113 & 0.316 \\
\hline Literate, higher secondary and above & 0.049 & 0.216 & 0.028 & 0.165 & 0.029 & 0.169 & 0.098 & 0.297 \\
\hline \multicolumn{9}{|l|}{ Occupation Variables } \\
\hline Self-employed in non-agriculture & 0.155 & 0.362 & 0.121 & 0.327 & 0.054 & 0.225 & 0.150 & 0.357 \\
\hline Self-employed in agriculture & 0.352 & 0.478 & 0.164 & 0.370 & 0.367 & 0.482 & 0.414 & 0.493 \\
\hline Agricultural labor & 0.313 & 0.464 & 0.540 & 0.498 & 0.441 & 0.497 & 0.209 & 0.406 \\
\hline Non-agricultural labor & 0.079 & 0.269 & 0.096 & 0.295 & 0.081 & 0.272 & 0.064 & 0.244 \\
\hline Miscellaneous & 0.102 & 0.303 & 0.078 & 0.269 & 0.057 & 0.232 & 0.163 & 0.370 \\
\hline Number of Observations & \multicolumn{2}{|c|}{23630} & \multicolumn{2}{|c|}{12316} & \multicolumn{2}{|c|}{9706} & \multicolumn{2}{|c|}{22171} \\
\hline
\end{tabular}

Notes: Sample means are calculated using the individual household multiplier.

Source: 55th round (1999/2000) of the consumer expenditure survey of the NSS. 


\section{Table 2: Sample Means, Urban Households}

Variables

Monthly Per Capita Expenditure
Log of Monthly Per Capita Expenditure

Demographic and Other Control Variables

Age

Household Size

\section{Education Variables}

Not Literate

Literate, below primary

Literate, below secondary

Literate, secondary

Literate, higher secondary and above

\section{Occupation Variables}

Self-employed

Regular wage/salary earning

Casual labor

Miscellaneous

Number of Observations
Other Backward Castes
Scheduled Castes

Mean

Mean S.D

849.743

686.897

S.D.

447.908
S.D.

6.546

Scheduled Tribes

Others

\section{es}

42.375
4.598

0.551

6.388

Mean

S.D.

Mean

S.D.

0.908

772.917

635.202

1143.760

1054.780

6.841

0.607

6.452

0.599

43.366

12.066
2.342

41.137

11.613

$40.866 \quad 11.235$

4.560

2.202

43.366

4.499

12.015

0.250

0.433

$0.133 \quad 0.339$

0.371

0.483

0.342

0.475

0.123

0.143

0.350

0.120

0.325

0.086

0.329

$0.301 \quad 0.459$

0.263

0.440

0.221

0.415

0.229

0.280

\subsection{3}

0.360

0.107

0.310

0.113

0.317

0.188

0.420

$0.163 \quad 0.370$

0.115

0.319

0.203

0.402

0.374

0.391

0.484

$\begin{array}{ll}0.379 & 0.485 \\ 0.366 & 0.482 \\ 0.186 & 0.389 \\ 0.069 & 0.253\end{array}$

$\begin{array}{ll}0.268 & 0.443 \\ 0.394 & 0.489 \\ 0.289 & 0.453 \\ 0.048 & 0.215 \\ 5670 & \end{array}$

\begin{tabular}{|c|c|}
\hline 0.238 & 0.426 \\
\hline 0.405 & 0.491 \\
\hline 0.254 & 0.435 \\
\hline 0.103 & 0.304 \\
\hline
\end{tabular}

\begin{tabular}{|c|c|}
\hline 0.364 & 0.481 \\
\hline 0.476 & 0.499 \\
\hline 0.077 & 0.267 \\
\hline 0.083 & 0.276 \\
\hline
\end{tabular}

Notes: Sample means are calculated using the individual household multiplier.

Source: 55th round (1999/2000) of the consumer expenditure survey of the NSS. 
Table 3: Determinants of (log) Monthly Per Capita Expenditure for Rural Households

\begin{tabular}{|c|c|c|c|c|}
\hline & $\begin{array}{c}\text { Other } \\
\text { Backward } \\
\text { Castes }\end{array}$ & $\begin{array}{l}\text { Scheduled } \\
\text { Castes }\end{array}$ & $\begin{array}{l}\text { Scheduled } \\
\text { Tribes }\end{array}$ & Others \\
\hline Intercept & $\begin{array}{l}6.208^{* * *} \\
(0.048)\end{array}$ & $\begin{array}{l}6.231^{* * *} \\
(0.062)\end{array}$ & $\begin{array}{l}6.092^{* * *} \\
(0.094)\end{array}$ & $\begin{array}{l}6.350^{* * *} \\
(0.063)\end{array}$ \\
\hline \multicolumn{5}{|l|}{ Demographic Control Variables } \\
\hline Age & $\begin{array}{l}0.015^{* * *} \\
(0.002)\end{array}$ & $\begin{array}{l}0.014^{* * *} \\
(0.002)\end{array}$ & $\begin{array}{l}0.012^{* * *} \\
(0.003)\end{array}$ & $\begin{array}{l}0.013^{* * *} \\
(0.002)\end{array}$ \\
\hline Age Square & $\begin{array}{l}-0.012^{* * *} \\
(0.002)\end{array}$ & $\begin{array}{l}-0.012^{* * *} \\
(0.003)\end{array}$ & $\begin{array}{l}-0.009^{* * *} \\
(0.003)\end{array}$ & $\begin{array}{l}-0.009^{* * *} \\
(0.003)\end{array}$ \\
\hline Household size & $\begin{array}{l}-0.128^{* * *} \\
(0.005)\end{array}$ & $\begin{array}{l}-0.147^{* * *} \\
(0.006)\end{array}$ & $\begin{array}{l}-0.138^{* * *} \\
(0.009)\end{array}$ & $\begin{array}{l}-0.126^{* * *} \\
(0.007)\end{array}$ \\
\hline Household size squared & $\begin{array}{l}0.005^{* * *} \\
(0.0003)\end{array}$ & $\begin{array}{l}0.006^{* * *} \\
(0.001)\end{array}$ & $\begin{array}{c}0.005^{* * *} \\
(0.001)\end{array}$ & $\begin{array}{l}0.004^{* * *} \\
(0.0005)\end{array}$ \\
\hline Land Owned (hectares) & $\begin{array}{l}0.039^{* * *} \\
(0.004)\end{array}$ & $\begin{array}{l}0.036^{* * *} \\
(0.006)\end{array}$ & $\begin{array}{l}0.034^{* * *} \\
(0.005)\end{array}$ & $\begin{array}{l}0.027^{* * *} \\
(0.003)\end{array}$ \\
\hline \multicolumn{5}{|c|}{ Education Variables - Reference Group: 'Not Literate' } \\
\hline Literate, below primary & $\begin{array}{l}0.067^{* * *} \\
(0.009)\end{array}$ & $\begin{array}{l}0.069^{* * *} \\
(0.011)\end{array}$ & $\begin{array}{l}0.090^{* * *} \\
(0.014)\end{array}$ & $\begin{array}{l}0.072^{* * *} \\
(0.010)\end{array}$ \\
\hline Literate, below secondary & $\begin{array}{l}0.153^{* * *} \\
(0.008)\end{array}$ & $\begin{array}{l}0.124^{* * *} \\
(0.011)\end{array}$ & $\begin{array}{l}0.146^{* * *} \\
(0.015)\end{array}$ & $\begin{array}{l}0.149^{* * *} \\
(0.009)\end{array}$ \\
\hline Literate, secondary & $\begin{array}{l}0.260^{* * *} \\
(0.014)\end{array}$ & $\begin{array}{l}0.207^{* * *} \\
(0.021)\end{array}$ & $\begin{array}{l}0.239^{* * *} \\
(0.032)\end{array}$ & $\begin{array}{l}0.274^{* * *} \\
(0.014)\end{array}$ \\
\hline Literate, higher secondary and above & $\begin{array}{l}0.382^{* * *} \\
(0.019)\end{array}$ & $\begin{array}{l}0.340^{* * *} \\
(0.032)\end{array}$ & $\begin{array}{l}0.324^{* * *} \\
(0.035)\end{array}$ & $\begin{array}{l}0.414^{* * *} \\
(0.018)\end{array}$ \\
\hline \multicolumn{5}{|c|}{ Occupation Variables - Reference Group: 'Miscelleneous' } \\
\hline Self-employed in non-agriculture & $\begin{array}{l}-0.023 \\
(0.014)\end{array}$ & $\begin{array}{l}-0.080^{* * *} \\
(0.022)\end{array}$ & $\begin{array}{l}-0.112^{* * *} \\
(0.035)\end{array}$ & $\begin{array}{l}-0.063^{* * *} \\
(0.015)\end{array}$ \\
\hline Self-employed in agriculture & $\begin{array}{c}-0.020 \\
(0.014)\end{array}$ & $\begin{array}{c}-0.048^{* *} \\
(0.021)\end{array}$ & $\begin{array}{l}-0.130^{* * *} \\
(0.031)\end{array}$ & $\begin{array}{l}-0.050^{* * *} \\
(0.014)\end{array}$ \\
\hline Agricultural labor & $\begin{array}{l}-0.176^{* * *} \\
(0.014)\end{array}$ & $\begin{array}{l}-0.192^{* * *} \\
(0.020)\end{array}$ & $\begin{array}{l}-0.228^{* * *} \\
(0.031)\end{array}$ & $\begin{array}{l}-0.230^{* * *} \\
(0.016)\end{array}$ \\
\hline Non-agricultural labor & $\begin{array}{l}-0.066^{* * *} \\
(0.017)\end{array}$ & $\begin{array}{l}-0.120^{* * *} \\
(0.025)\end{array}$ & $\begin{array}{l}-0.146^{* * *} \\
(0.037)\end{array}$ & $\begin{array}{l}-0.103^{* * *} \\
(0.018)\end{array}$ \\
\hline R-squared & 0.401 & 0.384 & 0.485 & 0.458 \\
\hline
\end{tabular}

Notes: a) Observations are weighted by the individual household multiplier. b) Dependent variable is the natural logarithm of monthly per capita expenditure. c) Standard errors in parentheses are robust to heteroskedasticity and clustered residuals within villages. d) $* * *$ and $* *$ denote significance at the 1 and 5 percent respectively. e) NSS region dummy variables included in all estimates. f) Though estimates are not reported, regional dummy variables are included in the regression estimation.

Source: 55th round (1999/2000) of the consumer expenditure survey of the NSS; our calculations. 
Table 4: The Determinants of (log) Monthly Per Capita Expenditure for Urban Households

\begin{tabular}{|c|c|c|c|c|}
\hline & $\begin{array}{l}\text { Other } \\
\text { Backward } \\
\text { Castes }\end{array}$ & $\begin{array}{l}\text { Scheduled } \\
\text { Castes }\end{array}$ & $\begin{array}{l}\text { Scheduled } \\
\text { Tribes }\end{array}$ & Others \\
\hline Intercept & $\begin{array}{l}6.613^{* * *} \\
(0.071)\end{array}$ & $\begin{array}{l}6.359^{* * *} \\
(0.098)\end{array}$ & $\begin{array}{l}6.292^{* * *} \\
(0.191)\end{array}$ & $\begin{array}{l}6.443^{* * *} \\
(0.071)\end{array}$ \\
\hline \multicolumn{5}{|l|}{ Demographic Control Variables } \\
\hline Age & $\begin{array}{l}0.011^{* * *} \\
(0.003)\end{array}$ & $\begin{array}{l}0.016^{* * *} \\
(0.004)\end{array}$ & $\begin{array}{l}0.017^{* *} \\
(0.008)\end{array}$ & $\begin{array}{l}0.020^{* * *} \\
(0.003)\end{array}$ \\
\hline Age Square & $\begin{array}{l}-0.008^{* *} \\
(0.003)\end{array}$ & $\begin{array}{l}-0.013^{* * *} \\
(0.004)\end{array}$ & $\begin{array}{l}-0.014 \\
(0.009)\end{array}$ & $\begin{array}{l}-0.013^{* * *} \\
(0.003)\end{array}$ \\
\hline Household size & $\begin{array}{l}-0.204^{* * *} \\
(0.008)\end{array}$ & $\begin{array}{l}-0.176^{* * *} \\
(0.013)\end{array}$ & $\begin{array}{l}-0.212^{* * *} \\
(0.019)\end{array}$ & $\begin{array}{l}-0.188^{* * *} \\
(0.007)\end{array}$ \\
\hline Household size squared & $\begin{array}{l}0.009^{* * *} \\
(0.001)\end{array}$ & $\begin{array}{l}0.007^{* * *} \\
(0.001)\end{array}$ & $\begin{array}{c}0.011^{* * *} \\
(0.002)\end{array}$ & $\begin{array}{l}0.008^{* * *} \\
(0.001)\end{array}$ \\
\hline \multicolumn{5}{|c|}{ Education Variables - Reference Group: ‘Not Literate’ } \\
\hline Literate, below primary & $\begin{array}{l}0.110^{* * *} \\
(0.017)\end{array}$ & $\begin{array}{l}0.092^{* * *} \\
(0.019)\end{array}$ & $\begin{array}{l}0.124^{* *} \\
(0.051)\end{array}$ & $\begin{array}{l}0.100^{* * *} \\
(0.018)\end{array}$ \\
\hline Literate, below secondary & $\begin{array}{l}0.197^{* * *} \\
(0.014)\end{array}$ & $\begin{array}{l}0.166^{* * *} \\
(0.018)\end{array}$ & $\begin{array}{l}0.240^{* * *} \\
(0.039)\end{array}$ & $\begin{array}{l}0.191^{* * *} \\
(0.017)\end{array}$ \\
\hline Literate, secondary & $\begin{array}{l}0.370^{* * *} \\
(0.018)\end{array}$ & $\begin{array}{l}0.249^{* * *} \\
(0.024)\end{array}$ & $\begin{array}{l}0.394^{* * *} \\
(0.049)\end{array}$ & $\begin{array}{l}0.374^{* * *} \\
(0.015)\end{array}$ \\
\hline Literate, higher secondary and above & $\begin{array}{l}0.596^{* * *} \\
(0.019)\end{array}$ & $\begin{array}{l}0.541^{* * *} \\
(0.029)\end{array}$ & $\begin{array}{l}0.704^{* * *} \\
(0.050)\end{array}$ & $\begin{array}{c}0.672^{* * *} \\
(0.023)\end{array}$ \\
\hline \multicolumn{5}{|c|}{ Occupation Variables - Reference Group: ‘Miscellaneous’ } \\
\hline Self-employed & $\begin{array}{c}0.034 \\
(0.027)\end{array}$ & $\begin{array}{c}0.041 \\
(0.041)\end{array}$ & $\begin{array}{c}0.038 \\
(0.088)\end{array}$ & $\begin{array}{l}-0.002 \\
(0.023)\end{array}$ \\
\hline Waged/salaried workers & $\begin{array}{l}0.082^{* * *} \\
(0.028)\end{array}$ & $\begin{array}{l}0.190^{* * *} \\
(0.038)\end{array}$ & $\begin{array}{c}0.133 \\
(0.085)\end{array}$ & $\begin{array}{l}-0.003 \\
(0.024)\end{array}$ \\
\hline Casual labor & $\begin{array}{l}-0.135^{* * *} \\
(0.030)\end{array}$ & $\begin{array}{l}-0.105^{* * *} \\
(0.038)\end{array}$ & $\begin{array}{l}-0.142^{*} \\
(0.086)\end{array}$ & $\begin{array}{l}-0.248^{* * *} \\
(0.036)\end{array}$ \\
\hline R-squared & 0.480 & 0.507 & 0.615 & 0.503 \\
\hline
\end{tabular}

Notes: a) Observations are weighted by the individual household multiplier. b) Dependent variable is the natural logarithm of monthly per capita expenditure. c) Standard errors in parentheses are robust to heteroskedasticity and clustered residuals within block. d) $* * *$ and $* *$ denote significance at the 1 and 5 percent respectively. e) NSS region dummy variables included in all estimates. f) Though estimates are not reported, regional dummy variables are included in the regression estimation.

Source: 55th round (1999/2000) of the consumer expenditure survey of the NSS; our calculations. 
Table 5: Decomposition of the Gap in Per Capita Expenditures Between Other Backward Castes vs. Others: Aggregate and Sub-Aggregate Effects

Characteristics Effect

Estimate $\quad$ Share (\%)
Coefficients Effect

Estimate

Share (\%)

$\underline{\text { Rural Households }}$

\begin{tabular}{|c|c|c|c|c|}
\hline Aggregate Effects & $\begin{array}{l}0.100^{* * *} \\
(0.008)\end{array}$ & 54.7 & $\begin{array}{l}0.083^{* * *} \\
(0.010)\end{array}$ & 45.3 \\
\hline Intercept & - & - & $\begin{array}{c}0.100 \\
(0.074)\end{array}$ & 54.6 \\
\hline $\begin{array}{l}\text { Land Owned } \\
\text { (hectares) }\end{array}$ & $\begin{array}{l}0.007^{* * *} \\
(0.001)\end{array}$ & 3.8 & $\begin{array}{c}-0.009^{* * *} \\
(0.003)\end{array}$ & -4.8 \\
\hline Age & $\begin{array}{l}0.004^{* * *} \\
(0.0002)\end{array}$ & 2.0 & $\begin{array}{l}-0.016 \\
(0.070)\end{array}$ & -9.0 \\
\hline Household Size & $\begin{array}{l}-0.004^{* * *} \\
(0.0001)\end{array}$ & -2.2 & $\begin{array}{c}0.005 \\
(0.024)\end{array}$ & 2.7 \\
\hline Education & $\begin{array}{l}0.041^{* * *} \\
(0.001)\end{array}$ & 22.5 & $\begin{array}{l}-0.007 \\
(0.005)\end{array}$ & -3.8 \\
\hline Occupation & $\begin{array}{l}0.023^{* * *} \\
(0.001)\end{array}$ & 12.4 & $\begin{array}{l}-0.004 \\
(0.004)\end{array}$ & -2.4 \\
\hline $\begin{array}{l}\text { NSS Region } \\
\text { Dummy Variables }\end{array}$ & $\begin{array}{l}0.030^{* * *} \\
(0.007)\end{array}$ & 16.2 & $\begin{array}{c}0.015 \\
(0.010)\end{array}$ & 8.1 \\
\hline \multicolumn{5}{|l|}{$\underline{\text { Urban Households }}$} \\
\hline Aggregate Effects & $\begin{array}{l}0.213^{* * *} \\
(0.009)\end{array}$ & 72.2 & $\begin{array}{c}0.082^{* * *} \\
(0.012)\end{array}$ & 27.8 \\
\hline Intercept & - & - & $\begin{array}{l}-0.190^{* *} \\
(0.094)\end{array}$ & -64.3 \\
\hline Age & $\begin{array}{c}0.009^{* * *} \\
(0.0005)\end{array}$ & 3.0 & $\begin{array}{l}0.244^{* * *} \\
(0.094)\end{array}$ & 82.7 \\
\hline Household Size & $\begin{array}{c}0.012^{* * *} \\
(0.0003)\end{array}$ & 4.0 & $\begin{array}{c}0.031 \\
(0.029)\end{array}$ & 10.5 \\
\hline Education & $\begin{array}{l}0.136^{* * *} \\
(0.004)\end{array}$ & 46.2 & $\begin{array}{l}-0.003 \\
(0.002)\end{array}$ & -1.0 \\
\hline Occupation & $\begin{array}{l}0.027^{* * *} \\
(0.003)\end{array}$ & 9.1 & $\begin{array}{l}-0.007 \\
(0.006)\end{array}$ & -2.4 \\
\hline $\begin{array}{l}\text { NSS Region } \\
\text { Dummy Variables }\end{array}$ & $\begin{array}{l}0.029^{* * *} \\
(0.008)\end{array}$ & 9.9 & $\begin{array}{c}0.007 \\
(0.012)\end{array}$ & 2.3 \\
\hline
\end{tabular}




\section{Table 6: Decomposition of the Gap in Per Capita Expenditures Between Scheduled} Castes vs. Others: Aggregate and Sub-Aggregate Effects

\begin{tabular}{|c|c|c|c|c|}
\hline \multirow{3}{*}{ Rural Households } & \multicolumn{2}{|c|}{ Characteristics Effect } & \multicolumn{2}{|c|}{ Coefficients Effect } \\
\hline & Estimate & Share(\%) & Estimate & Share(\%) \\
\hline & \multicolumn{4}{|c|}{$\underline{\text { Rural Households }}$} \\
\hline Aggregate Effects & $\begin{array}{c}0.168^{* * *} \\
(0.008)\end{array}$ & 56.2 & $\begin{array}{l}0.131^{* * *} \\
(0.011)\end{array}$ & 43.8 \\
\hline Intercept & - & - & $\begin{array}{c}0.030 \\
(0.079)\end{array}$ & 10.2 \\
\hline Land Owned (hectares) & $\begin{array}{c}0.018^{* * *} \\
(0.002)\end{array}$ & 5.9 & $\begin{array}{c}-0.003 \\
(0.002)\end{array}$ & -0.9 \\
\hline Age & $\begin{array}{l}0.010^{* * *} \\
(0.001)\end{array}$ & 3.4 & $\begin{array}{c}0.033 \\
(0.075)\end{array}$ & 11.0 \\
\hline Household Size & $\begin{array}{c}-0.016^{* * *} \\
(0.001)\end{array}$ & -5.2 & $\begin{array}{c}0.050^{*} \\
(0.026)\end{array}$ & 16.6 \\
\hline Education & $\begin{array}{l}0.065^{* * *} \\
(0.002)\end{array}$ & 21.8 & $\begin{array}{c}-0.024^{* * *} \\
(0.008)\end{array}$ & -8.1 \\
\hline Occupation & $\begin{array}{l}0.065^{* * *} \\
(0.004)\end{array}$ & 21.8 & $\begin{array}{c}-0.016^{* * *} \\
(0.006)\end{array}$ & -5.4 \\
\hline NSS Region Dummy Variables & $\begin{array}{l}0.026^{* * *} \\
(0.006)\end{array}$ & 8.6 & $\begin{array}{l}0.061^{* * *} \\
(0.010)\end{array}$ & 20.4 \\
\hline \multicolumn{5}{|l|}{ Urban Households } \\
\hline Aggregate Effects & $\begin{array}{c}0.320^{* * *} \\
(0.006)\end{array}$ & 70.6 & $\begin{array}{c}0.133^{* * *} \\
(0.012)\end{array}$ & 29.4 \\
\hline Intercept & - & - & $\begin{array}{c}0.016 \\
(0.111)\end{array}$ & 3.5 \\
\hline Age & $\begin{array}{c}0.019^{* * *} \\
(0.001)\end{array}$ & 4.1 & $\begin{array}{l}0.178 * \\
(0.105)\end{array}$ & 39.3 \\
\hline Household Size & $\begin{array}{c}0.037^{* * *} \\
(0.001)\end{array}$ & 8.1 & $\begin{array}{l}-0.037 \\
(0.040)\end{array}$ & -8.1 \\
\hline Education & $\begin{array}{l}0.192^{* * *} \\
(0.006)\end{array}$ & 42.4 & $\begin{array}{c}-0.022^{* * *} \\
(0.005)\end{array}$ & -4.8 \\
\hline Occupation & $\begin{array}{l}0.052^{* * *} \\
(0.005)\end{array}$ & 11.5 & $\begin{array}{c}-0.034^{* * *} \\
(0.009)\end{array}$ & -7.5 \\
\hline NSS Region Dummy Variables & $\begin{array}{l}0.020^{* * *} \\
(0.003)\end{array}$ & 4.5 & $\begin{array}{c}0.031^{* * *} \\
(0.011)\end{array}$ & 6.9 \\
\hline
\end{tabular}

Note: a) Standard errors in parentheses. b) ***, **, and * denote significance at the 1,5 and 10 percent respectively. c) Share is the percentage of 0.299 log-points in rural, and of 0.453 log-points in urban. Source: 55th round (1999/2000) of the consumer expenditure survey of the NSS. 


\section{Table 7: Decomposition of the Gap in Per Capita Expenditures Between Scheduled Tribes vs. Others Aggregate and Sub-Aggregate Effects}

\begin{tabular}{|c|c|c|c|c|}
\hline \multirow{3}{*}{ Rural Households } & \multicolumn{2}{|c|}{ Characteristics Effect } & \multicolumn{2}{|c|}{ Coefficients Effect } \\
\hline & Estimate & Share(\%) & Estimate & Share(\%) \\
\hline & & & & \\
\hline Aggregate Effects & $\begin{array}{l}0.207^{* * *} \\
(0.012)\end{array}$ & 53.5 & $\begin{array}{c}0.180^{* * *} \\
(0.015)\end{array}$ & 46.5 \\
\hline Intercept & - & - & $\begin{array}{c}0.043 \\
(0.085)\end{array}$ & 11.1 \\
\hline Land Owned (hectares) & $\begin{array}{c}0.004^{* * *} \\
(0.0004)\end{array}$ & 1.1 & $\begin{array}{l}-0.006 \\
(0.005)\end{array}$ & -1.5 \\
\hline Age & $\begin{array}{l}0.013^{* * *} \\
(0.001)\end{array}$ & 3.3 & $\begin{array}{c}0.050 \\
(0.082)\end{array}$ & 13.0 \\
\hline Household Size & $\begin{array}{c}-0.009^{* * *} \\
(0.001)\end{array}$ & -2.4 & $\begin{array}{c}0.045 \\
(0.032)\end{array}$ & 11.6 \\
\hline Education & $\begin{array}{l}0.071^{* * *} \\
(0.003)\end{array}$ & 18.4 & $\begin{array}{l}-0.020^{* *} \\
(0.010)\end{array}$ & -5.2 \\
\hline Occupation & $\begin{array}{l}0.047^{* * *} \\
(0.003)\end{array}$ & 12.1 & $\begin{array}{c}0.0003 \\
(0.008)\end{array}$ & 0.1 \\
\hline NSS Region Dummy Variables & $\begin{array}{l}0.081^{* * *} \\
(0.011)\end{array}$ & 21.0 & $\begin{array}{c}0.067^{* * *} \\
(0.015)\end{array}$ & 17.4 \\
\hline Urban Households & & & & \\
\hline Aggregate Effects & $\begin{array}{l}0.260^{* * *} \\
(0.010)\end{array}$ & 66.8 & $\begin{array}{c}0.129^{* * *} \\
(0.018)\end{array}$ & 33.2 \\
\hline Intercept & - & - & $\begin{array}{c}-0.014 \\
(0.185)\end{array}$ & -3.7 \\
\hline Age & $\begin{array}{l}0.020^{* * *} \\
(0.001)\end{array}$ & 5.1 & $\begin{array}{c}0.125 \\
(0.178)\end{array}$ & 32.2 \\
\hline Household Size & $\begin{array}{l}0.012^{* * *} \\
(0.001)\end{array}$ & 3.2 & $\begin{array}{c}0.032 \\
(0.056)\end{array}$ & 8.2 \\
\hline Education & $\begin{array}{l}0.141^{* * *} \\
(0.004)\end{array}$ & 36.3 & $\begin{array}{c}0.003 \\
(0.007)\end{array}$ & 0.7 \\
\hline Occupation & $\begin{array}{l}0.043^{* * *} \\
(0.004)\end{array}$ & 11.2 & $\begin{array}{c}-0.021 \\
(0.013)\end{array}$ & -5.4 \\
\hline NSS Region Dummy Variables & $\begin{array}{l}0.043^{* * *} \\
(0.009)\end{array}$ & 11.1 & $\begin{array}{c}0.005 \\
(0.013)\end{array}$ & 1.3 \\
\hline
\end{tabular}

Note: a) Standard errors in parentheses. b) ***, **, and * denote significance at the 1, 5 and 10 percent respectively. c) Share is the percentage of 0.387 log-points in rural, and of 0.389 log-points in urban. Source: 55th round (1999/2000) of the consumer expenditure survey of the NSS. 